Article

\title{
Rapid Immobilization of Simulated Radioactive Soil Waste Using Self-Propagating Synthesized $\mathrm{Gd}_{2} \mathrm{Ti}_{2} \mathrm{O}_{7}$ Pyrochlore Matrix
}

\author{
Jiali Xue ${ }^{1}$, Kuibao Zhang ${ }^{1,2, *}$, Zongsheng He ${ }^{1}$, Wenwen Zhao ${ }^{1}$, Weiwei Li $^{1}$, Dayan Xie ${ }^{1}$, \\ Baozhu Luo ${ }^{1}$, Kai $\mathrm{Xu}^{3}$ and Haibin Zhang ${ }^{4, *}$ \\ 1 State Key Laboratory of Environment-friendly Energy Materials, Southwest University of Science and \\ Technology, Mianyang 621010, China; xuejiali0304@163.com (J.X.); hezongsheng@swust.edu.cn (Z.H.); \\ zhaowenwen@swust.du.cn (W.Z.); liweiwei@swust.du.cn (W.L.); xiedayan@swust.edu.cn (D.X.); \\ luobaozhu@swust.edu.cn (B.L.) \\ 2 Sichuan Civil-Military Integration Institute, Mianyang 621010, China \\ 3 State Key Laboratory of Silicate Materials for Architectures, Wuhan University of Technology, \\ Wuhan 430070, China; kaixu@whut.edu.cn \\ 4 Institute of Nuclear Physics and Chemistry, China Academy of Engineering Physics, \\ Mianyang 621900, China \\ * Correspondence: zhangkuibao@swust.edu.cn (K.Z.); hbzhang@caep.cn (H.Z.); Tel.: +86-816-241-9492 (K.Z.)
}

Received: 22 February 2019; Accepted: 8 April 2019; Published: 10 April 2019

\begin{abstract}
A rapid and effective method is necessary in the disposal of severely radioactive contaminated soil waste. Simulated Ce-bearing radioactive soil waste was immobilized by self-propagating high-temperature synthesis (SHS) within $5 \mathrm{~min}$ in this study. The main work includes the rapid synthesis of soil waste forms, the analysis of phase composition, microstructure and chemical durability. These results show that the simulated nuclide Ce was successfully immobilized into the pyrochlore-rich waste matrice, whose main phases are $\mathrm{SiO}_{2}$, pyrochlore $\left(\mathrm{Gd}_{2} \mathrm{Ti}_{2} \mathrm{O}_{7}\right)$ and $\mathrm{Cu}$. The normalized leaching rates of $\mathrm{Si}$ and $\mathrm{Na}$ on the 42 nd day are $1.86 \times 10^{-3}$ and $1.63 \times 10^{-2} \mathrm{~g} \cdot \mathrm{m}^{-2} \cdot \mathrm{d}^{-1}$, respectively. And the normalized leaching rate of Ce also remains at low level $\left(10^{-5}-10^{-6} \mathrm{~g} \cdot \mathrm{m}^{-2} \cdot \mathrm{d}^{-1}\right)$ within 42 days.
\end{abstract}

Keywords: Radioactive soil waste; $\mathrm{Gd}_{2} \mathrm{Ti}_{2} \mathrm{O}_{7}$ pyrochlore; $\mathrm{SHS} ; \mathrm{CeO}_{2} ;$ Immobilization

\section{Introduction}

In recent years, nuclear power has been developed rapidly in the world due to its advantages of high efficiency, economy and low carbon emissions. However, the harm caused by the byproduction of nuclear energy, mainly nuclear wastes, can hardly be ignored, especially high-level radioactive waste (HLW) [1]. The radioactive nuclides in HLW, such as ${ }^{137} \mathrm{Cs},{ }^{90} \mathrm{Sr},{ }^{239} \mathrm{Pu},{ }^{235} \mathrm{U}$, etc., possess the characteristics of long half-life, high toxicity, and high heat generation [2,3]. When these radionuclides enter the soil, the situation becomes more complicated because the presence of soil will increase the cost of disposal [4,5]. Furthermore, soil contaminated by highly radioactive nuclides may pose a long-term threat to organisms due to ecological cycling [6,7].

For radioactive contaminated soil, sand is an inseparable main substance and must be cured together with radionuclides. At present, there are mainly physical landfill and bioremediation methods for the treatment of radioactive contaminated soil. The physical landfill is a time-consuming project, which will destroy the ecosystem of disposal area. At the same time, it may cause further pollution due to leakage during transportation [8]. The bioremediation method requires a long period of restoration, and the growth of plants is limited by climate and geology [9]. In addition to the above methods, vitrification is an effective technology for the immobilization of long half-life wastes, especially for soil 
wastes contaminated by high radioactive nuclides $[10,11]$. Particularly, borosilicate glass is the most widely studied and utilized vitrified waste form in the world because of its good radiation resistance, corrosion resistance, and chemical stability [12]. Regrettably, the glass matrice may decompose in geological repositories due to high temperature and high pressure $[13,14]$. Furthermore, the relatively low thermal stability of vitrified waste forms is also a potential limitation [15]. Compared with glass matrice, ceramic solidified bodies have the advantages of low expansion rate, excellent mechanical properties, and good chemical stability. Subsequently, Synroc has been proposed as a potential alternative host matrix for HLW immobilization based on the isomorphism substitution theory [16-20].

Self-propagating high-temperature synthesis (SHS) is a technology that uses the energy released by exothermic redox reactions to synthesize the final products [21-23]. SHS technology possesses certain technical and cost advantages in the treatment of contaminated soil. According to the characteristics of radionuclides, the composition and proportion of a SHS reaction system can be well designed. In addition, quick pressing $(\mathrm{QP})$ is also introduced to obtain compact samples [24]. Zirconolite-rich matrice and titanate-pyrochlore with excellent chemical durability can also be prepared by SHS/QP [25-30]. SHS/QP technology can synthesize high density ceramic matrix in several minutes, which was considered as a potential method to deal with environmental issues. In this study, $\mathrm{Gd}_{2} \mathrm{Ti}_{2} \mathrm{O}_{7}$ pyrochlore waste matrix was synthesized by SHS for the disposal of simulated radioactive soil waste. Ten wt.\% $\mathrm{CeO}_{2}$ was regarded as a simulate of tetravalent actinide [31]. Silica sand was utilized as the heat insulation material and pressure transfer medium during the SHS/QP process. A series of characterizations were carried out to understand the solidifying mechanism of obtained waste forms. In addition, the aqueous durability was evaluated using the standard Product Consistency Test (PCT) method [32].

\section{Materials and Methods}

The composition of original soil is listed in Table 1. The soil (200 meshes) and simulated radionuclide $\mathrm{Ce}^{4+}\left(\mathrm{CeO}_{2}\right.$, Aladdin Industrial Inc., purity $\left.\left.\geq 99.99 \%\right)\right)$ were mixed with the weight ratio of 9:1. The SHS reaction was prepared according to the following chemical equation [28]:

$$
4 \mathrm{CuO}+\mathrm{Gd}_{2} \mathrm{O}_{3}+2 \mathrm{Ti}=\mathrm{Gd}_{2} \mathrm{Ti}_{2} \mathrm{O}_{7}+4 \mathrm{Cu}
$$

The raw materials of $\mathrm{CuO}, \mathrm{Gd}_{2} \mathrm{O}_{3}$, and $\mathrm{Ti}$ (purity $\geq 99.9$ wt.\%) were purchased from Aladdin Industrial Inc. (Shanghai, China). Different contents of simulated radioactive soil wastes (0 wt.\%, $5 \mathrm{wt} . \%, 10 \mathrm{wt} . \%, 15 \mathrm{wt} . \%, 20 \mathrm{wt} . \%, 25 \mathrm{wt} . \%)$ were mixed with the raw materials of SHS reaction (labelled as $\mathrm{Cu}-0, \mathrm{Cu}-5, \mathrm{Cu}-10, \mathrm{Cu}-15, \mathrm{Cu}-20$, and $\mathrm{Cu}-25$, respectively). Pretreatment of powder samples is similar as the previous study [28].

Table 1. Soil composition in this study.

\begin{tabular}{ccccccccc}
\hline Composition & $\mathrm{SiO}_{2}$ & $\mathrm{Al}_{2} \mathrm{O}_{3}$ & $\mathrm{Fe}_{2} \mathrm{O}_{3}$ & $\mathrm{CaO}$ & $\mathrm{K}_{2} \mathbf{O}$ & $\mathbf{M g O}$ & $\mathrm{Na}_{2} \mathrm{O}$ & $\mathrm{TiO}_{2}$ \\
\hline Content (wt.\%) & 66.32 & 16.57 & 5.87 & 4.67 & 2.86 & 1.66 & 0.81 & 0.74 \\
\hline
\end{tabular}

The SHS/QP process is shown in Figure 1. The self-propagating combustion reactions were ignited by tungsten wire, which was located at one side with tight contact of the green body and heated by a direct current of about $50 \mathrm{~A}$. The SHS reactants were ignited at high temperature, and the combustion wave automatically propagated to the unreacted region until the reaction's completion. Before densification, the $W / \operatorname{Re} 5 / 26$ thermocouple was placed in the center of the samples to measure the reaction temperature of $\mathrm{Cu}-0$ to $\mathrm{Cu}-25$ specimens. The unpressurized samples were crushed into fine powders for X-ray diffraction analysis (XRD; X'Pert PRO, PANalytical B.V., Almelo, The Netherlands). 


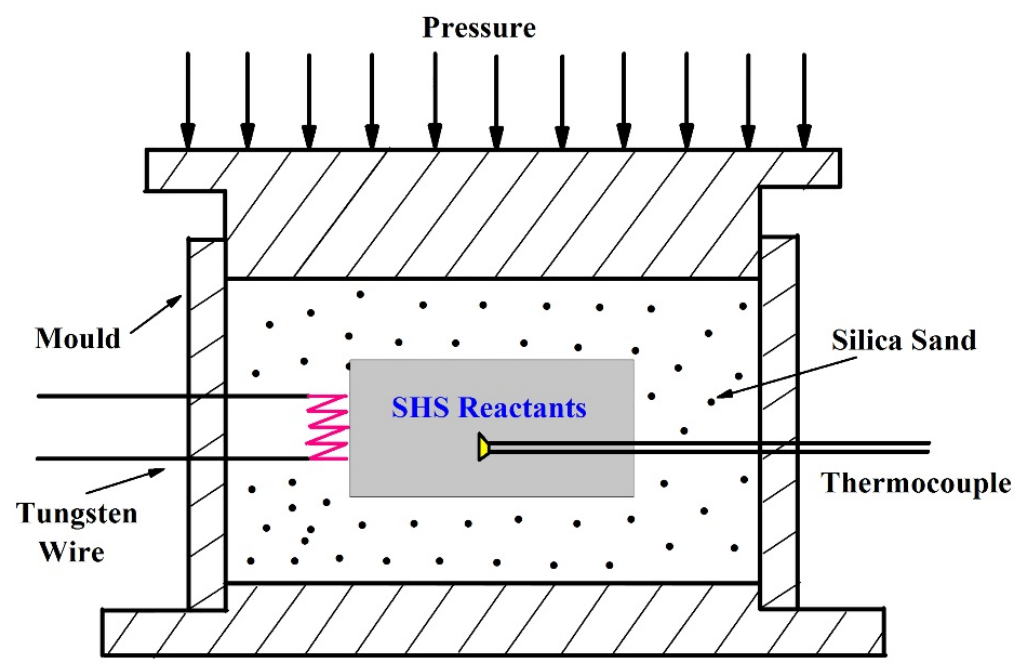

Figure 1. Diagrammatic sketch of the self-propagating high-temperature synthesis/quick pressing (SHS/QP) process.

For densification, the ignited sample was compressed by $50 \mathrm{MPa}$ with $60 \mathrm{~s}$ dwelling time after proper combustion delay time. The SHS-ed compact sample was cut and polished to characterize the microstructure and elemental distribution using field-emission scanning electron microscopy (FESEM; Zeiss Ultra-55, Oberkochen, Germany) and energy-dispersive X-ray spectroscopy (EDX, ULTRA 55, ZEISS, Oberkochen, Germany). The chemical durability of waste form was tested by the Product Consistency Test (PCT) standard. The concentrations of Na and Si in leachate were determined by inductively coupled plasma (ICP) analysis (iCPA 6500, ThermoFisher, Waltham, MA, USA), while that of Ce was obtained by inductively coupled plasma-mass spectrometry (ICP-MS) analysis using an Agilent 7700× spectrometer (Agilent, Santa Clara, CA, USA). The normalized release rates were calculated as the following formula:

$$
N R_{i}=\frac{C_{i} \cdot V}{f_{i} \cdot S_{A} \cdot t}
$$

where $C_{i}$ is the concentration of element $i$ in the solution, $V$ is the volume of the leachate $\left(\mathrm{m}^{3}\right), S_{A}$ is the surface area of powder specimen $\left(\mathrm{m}^{2}\right), f_{i}$ is the mass fraction of element $i$ in the sample (wt.\%) and $t$ is the leaching duration (d). The $S_{A} / V$ ratio is about $2000 \mathrm{~m}^{-1}$, which is derived from the standard test method for The Product Consistency Test (ASTM c 1285-02) [32]. In this standard, the waste particles are assumed to be spherical and the average particle diameter is $1.12 \times 10^{-4} \mathrm{~m}$ for $-100(0.149 \mathrm{~mm})$ to $+200(0.074 \mathrm{~mm})$ meshes particles. Therefore, the average particle area and volume are calculated as $3.90 \times 10^{-8} \mathrm{~m}^{2}$ and $7.25 \times 10^{-13} \mathrm{~m}^{3}$, respectively. The average particle mass is calculated to be $1.96 \times 10^{-6} \mathrm{~g}$. Thus, there are $1 \mathrm{~g} / 1.96 \times 10^{-6} \mathrm{~g}=5.11 \times 10^{5}$ particles in $1 \mathrm{~g}$ powder waste form with -100 to +200 meshes particles. Thus, the total surface area of $1 \mathrm{~g}$ powder with -100 to +200 meshes particles is calculated to be $1.99 \times 10^{-2} \mathrm{~m}^{2}$. As long as the density and particle size of waste form remain comparable during the leaching tests, this parameter will remain at a constant value and doesn't need to be calculated every time.

\section{Results and Discussion}

\subsection{Temperature and Powder XRD Analysis}

The combustion process of the designed SHS reaction takes about $10 \mathrm{~s}$ after tungsten wire ignition. The center temperature of all samples in SHS reactions are measured and depicted in Figure 2. With the increment of soil wastes, the center temperatures of $\mathrm{Cu}-0, \mathrm{Cu}-5, \mathrm{Cu}-10, \mathrm{Cu}-15, \mathrm{Cu}-20$, and $\mathrm{Cu}-25$ samples decrease from 1679 to $1052{ }^{\circ} \mathrm{C}$ in Figure 2. The center temperature of the $\mathrm{Cu}-0$ sample is the highest at $1679{ }^{\circ} \mathrm{C}$, while the $\mathrm{Cu}-25$ sample with the maximum soil content exhibits 
the lowest temperature at $1052{ }^{\circ} \mathrm{C}$. Apparently, the increase of soil wastes led to the decrease of SHS reaction temperature.

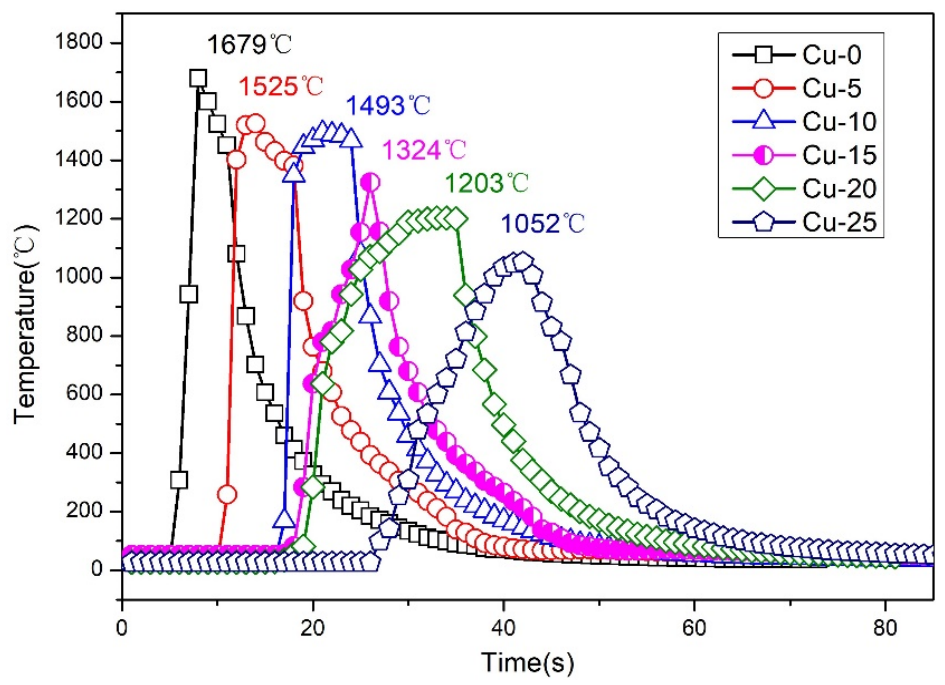

Figure 2. Real temperature curves of all samples during SHS reaction.

The XRD patterns in Figure 3 show that the specimens with soil waste ( $\mathrm{Cu}-5$ to $\mathrm{Cu}-25$ samples) are composed of $\mathrm{Cu}, \mathrm{SiO}_{2}$, and $\mathrm{Gd}_{2} \mathrm{Ti}_{2} \mathrm{O}_{7}$ (PDF No. 23-0259), while the sample without soil waste only contains $\mathrm{Gd}_{2} \mathrm{Ti}_{2} \mathrm{O}_{7}$ pyrochlore. From $\mathrm{Cu}-5$ to $\mathrm{Cu}-25$ specimens, the main phase of all samples is $\mathrm{Gd}_{2} \mathrm{Ti}_{2} \mathrm{O}_{7}$ pyrochlore, demonstrating that the increase of soil wastes does not change the phase composition. In Figure 3, the content of $\mathrm{Cu}$ in these SHS-ed samples increases with the increment of soil content, but $\mathrm{Cu}$ is hardly found in the $\mathrm{Cu}-0$ sample. Because the temperature of $\mathrm{Cu}-0$ reaction is the highest, the $\mathrm{Cu}$ melts and condenses into bulky grains during the high temperature reaction. With the decrease of reaction temperature, the size of copper particles decreases. Meanwhile, all SHS-ed samples were ground into powder for XRD testing, where the granulated $\mathrm{Cu}$ was sifted out directly. By contrast, the content change of $\mathrm{SiO}_{2}$ has no regular pattern, which may be affected by the heat insulator silica sand. However, unknown phases appear in the $\mathrm{Cu}-25$ sample, which may be related with the large amount of simulated radioactive soil. Therefore, the $\mathrm{Cu}-20$ specimen was selected for further analysis.

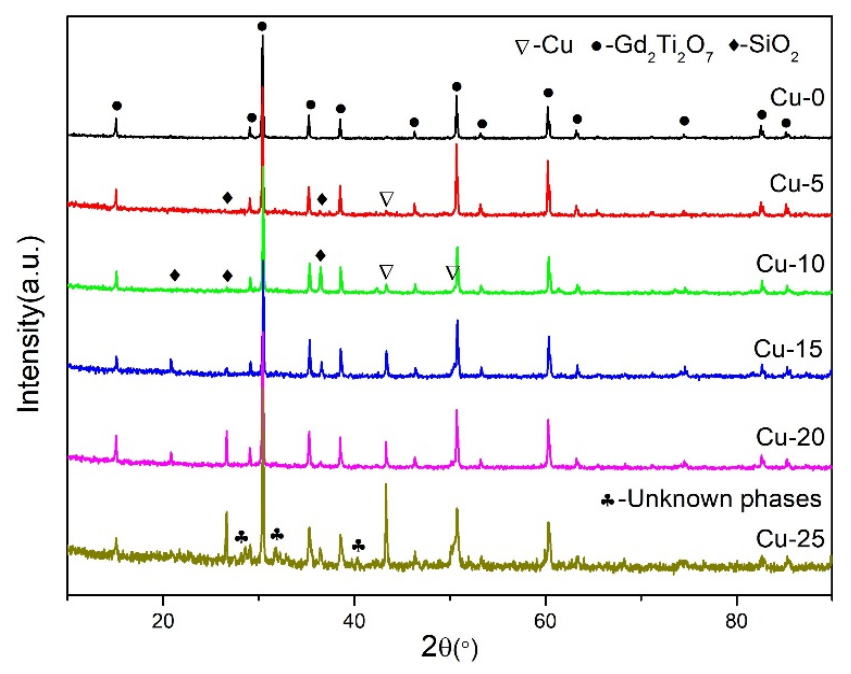

Figure 3. X-ray diffraction (XRD) patterns of all SHS-ed samples. 


\subsection{Raman Analysis and Microstructure Characterization}

Raman spectroscopy was carried out to further analyze the crystal structure and internal bonds of pyrochlore. Raman spectroscopy is an important technique, especially in systems where oxygen displacement induces structure transformation, such as distinguishing fluorite from pyrochlore in pyrochlore ceramics [33]. Different from the $\mathrm{A}_{2} \mathrm{~B}_{2} \mathrm{O}_{7}$ fluorite structure with only one $\mathrm{F}_{2 g}$ vibration mode, the pyrochlore structure contains six Raman modes $\left(\mathrm{A}_{1 \mathrm{~g}}, \mathrm{E}_{\mathrm{g}}\right.$, and $\left.4 \mathrm{~F}_{2 \mathrm{~g}}\right)$. Typical wavenumbers of pyrochlore phase at room temperature are $520 \mathrm{~cm}^{-1}\left(\mathrm{~A}_{1 \mathrm{~g}}\right), 330 \mathrm{~cm}^{-1}\left(\mathrm{E}_{\mathrm{g}}\right)$, and 200, 310, 450, $580 \mathrm{~cm}^{-1}$ $\left(4 \mathrm{~F}_{2 \mathrm{~g}}\right)[33,34]$. For Ti-pyrochlore, the most prominent characteristic of Raman spectra are the intensive band at $320 \mathrm{~cm}^{-1}$ and the $A_{1 g}$ band at $520 \mathrm{~cm}^{-1}$. The band around $320 \mathrm{~cm}^{-1}$ includes $E_{\mathrm{g}}+\mathrm{F}_{2 \mathrm{~g}}$ modes with very close frequency, which is mostly attributed to $\mathrm{O}-\mathrm{A}-\mathrm{O}$ bond vibration. The $\mathrm{A}_{1 g}$ band at $520 \mathrm{~cm}^{-1}$ is believed to be related to A-O stretching [35,36].

The Raman spectra of $\mathrm{Cu}-0, \mathrm{Cu}-10$, and $\mathrm{Cu}-20$ samples are shown in Figure 4. The six Raman active vibration modes $\left(\mathrm{A}_{1 \mathrm{~g}}, \mathrm{E}_{\mathrm{g}}\right.$ and $\left.4 \mathrm{~F}_{2 \mathrm{~g}}\right)$ are explicitly assigned. In addition, the $\mathrm{Si}-\mathrm{O}$ stretching vibration at $1100 \mathrm{~cm}^{-1}$ and the $\mathrm{Si}-\mathrm{O}-\mathrm{Si}$ symmetric bending vibration near $700 \mathrm{~cm}^{-1}$ are also included. The Raman spectra peaks of three specimens are similar except for some changes in strength, which means the pyrochlore structure of $\mathrm{Gd}_{2} \mathrm{Ti}_{2} \mathrm{O}_{7}$ remains unchanged. In particular, the characteristic $\mathrm{F}_{2 \mathrm{~g}}$ $\left(200 \mathrm{~cm}^{-1}\right.$ and $\left.455 \mathrm{~cm}^{-1}\right)$ bands are well defined in the $\mathrm{Cu}-0$ specimen. On the contrary, the vibration intensity of $\mathrm{E}_{\mathrm{g}}+\mathrm{F}_{2 \mathrm{~g}}$ modes $\left(320 \mathrm{~cm}^{-1}\right)$ and $\mathrm{A}_{1 \mathrm{~g}}$ mode $\left(520 \mathrm{~cm}^{-1}\right)$ increase significantly in the $\mathrm{Cu}-10$ and $\mathrm{Cu}-20$ samples. It is evident that this drastic change is due to the addition of simulated radioactive soil. On the basis of previous literatures [33-36], we preliminarily speculate that some ions in the simulated radioactive soil (possibly containing Ce) occupy the A and B sites of pyrochlore structure, resulting in steep changes of oxygen ions' environment and peak intensity of Raman spectra.

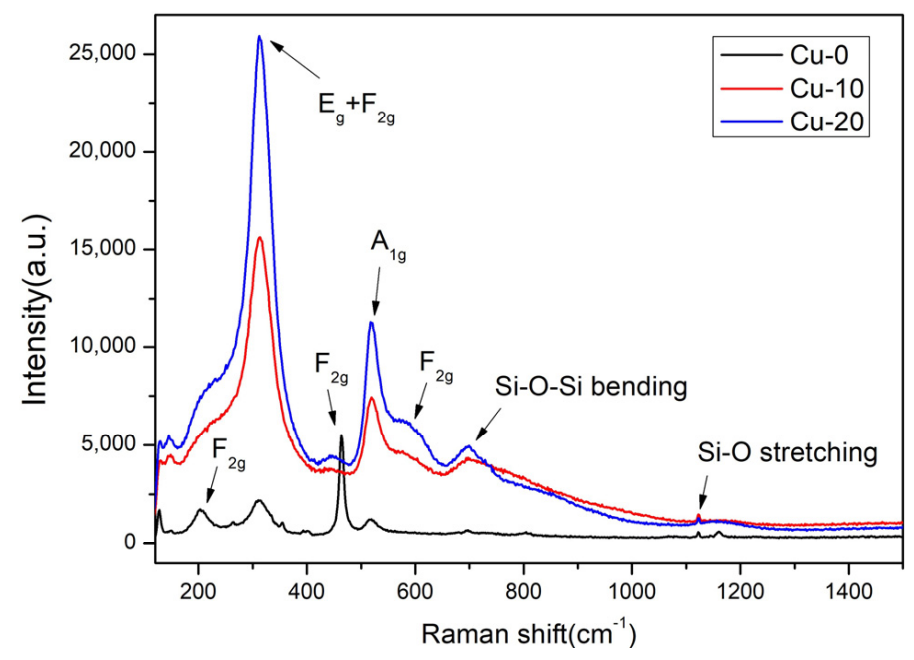

Figure 4. Raman spectra of the $\mathrm{Cu}-0, \mathrm{Cu}-10$, and $\mathrm{Cu}-20$ samples.

As shown in Figure 5, the microstructure and elemental distribution of the compact $\mathrm{Cu}-20$ specimen are exhibited in the SEM and elemental mapping images. It can be found that the pores mainly exist in the ceramic matrix rather than the copper phase. It may be argued that the melting point of copper $\left(1083.4^{\circ} \mathrm{C}\right)$ is lower than the combustion temperature of the $\mathrm{Cu}-20$ sample. Therefore, gas can easily be discharged from the copper into the ceramic matrix. The $\mathrm{Cu}-20$ sample consists of four phases, labeled as A, B, C, D in Figure 5a. According to Figure $5 b-f$ and XRD analysis, we speculate that the $\mathrm{A}$ region is copper, the $\mathrm{B}$ region should be $\mathrm{Gd}_{2} \mathrm{Ti}_{2} \mathrm{O}_{7}$, the $\mathrm{C}$ region is $\mathrm{SiO}_{2}$, and the $\mathrm{D}$ region represents $\mathrm{TiO}_{2}$. The impurity $\mathrm{TiO}_{2}$ phase is produced from the raw materials of the reaction system and the original soil. However, no $\mathrm{TiO}_{2}$ exists in the previous XRD result of $\mathrm{Cu}-20$. It is possible that the diffraction peaks of $\mathrm{TiO}_{2}$ are not obvious because of its low content. 

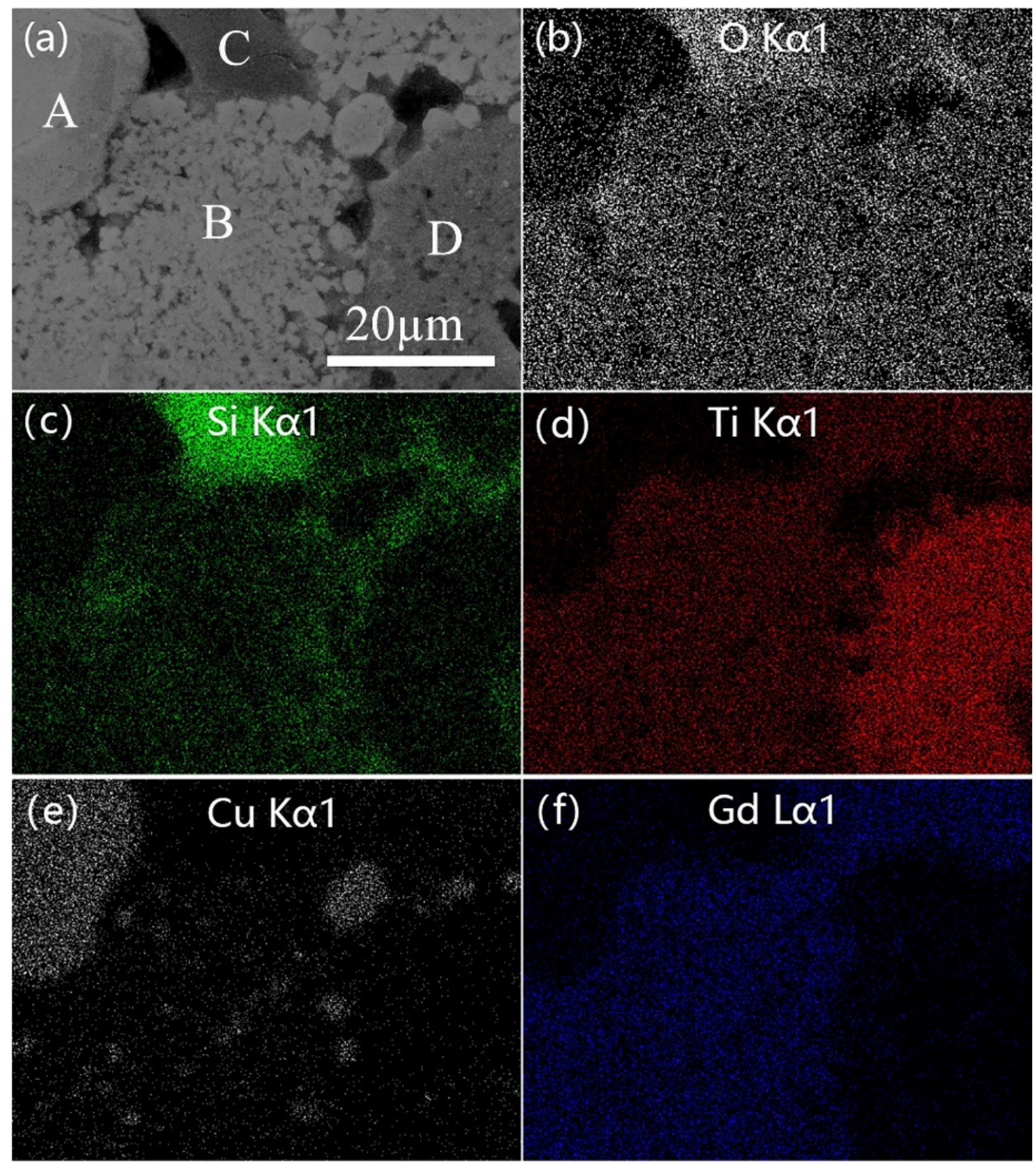

Figure 5. (a) SEM image of Cu-20 specimen, and element mapping images of (b) O, (c) $\mathrm{Si}$, (d) Ti, (e) Cu, (f) Gd.

The EDX elemental spotting analysis of the Cu-20 sample is presented in Figure 6. The EDX spotting image of " $\mathrm{B}$ " phase in Figure 6a is presented in Figure $6 \mathrm{~b}$. Combined with the XRD and EDX mapping results, the existence of $\mathrm{Gd}, \mathrm{Ti}, \mathrm{Ce}$, and $\mathrm{O}$ in the EDX spotting spectra indicates that the " $\mathrm{B}$ " phase is Ce doped $\mathrm{Gd}_{2} \mathrm{Ti}_{2} \mathrm{O}_{7}$ pyrochlore phase. The average elemental quantities are acquired by taking at least five points of " $\mathrm{A}$ " area as listed in the inserted table of Figure 6b, which results in the chemical formulation of $\mathrm{Gd}_{1.96} \mathrm{Ti}_{1.94} \mathrm{Ce}_{0.09} \mathrm{O}_{7}$. Meanwhile, a small amount of $\mathrm{Ce}$ is also found in the soil phase according to Figure $6 c$, indicating that the simulated nuclide Ce of radioactive soil waste can exist in both the pyrochlore phase and soil phase. At the same time, most of the elements in original soil are retained in the soil phase. Figure $6 \mathrm{~d}$ shows that only $\mathrm{Ti}$ and $\mathrm{O}$ are present in the $\mathrm{D}$ region, which confirms that the $\mathrm{D}$ phase is $\mathrm{TiO}_{2}$. 

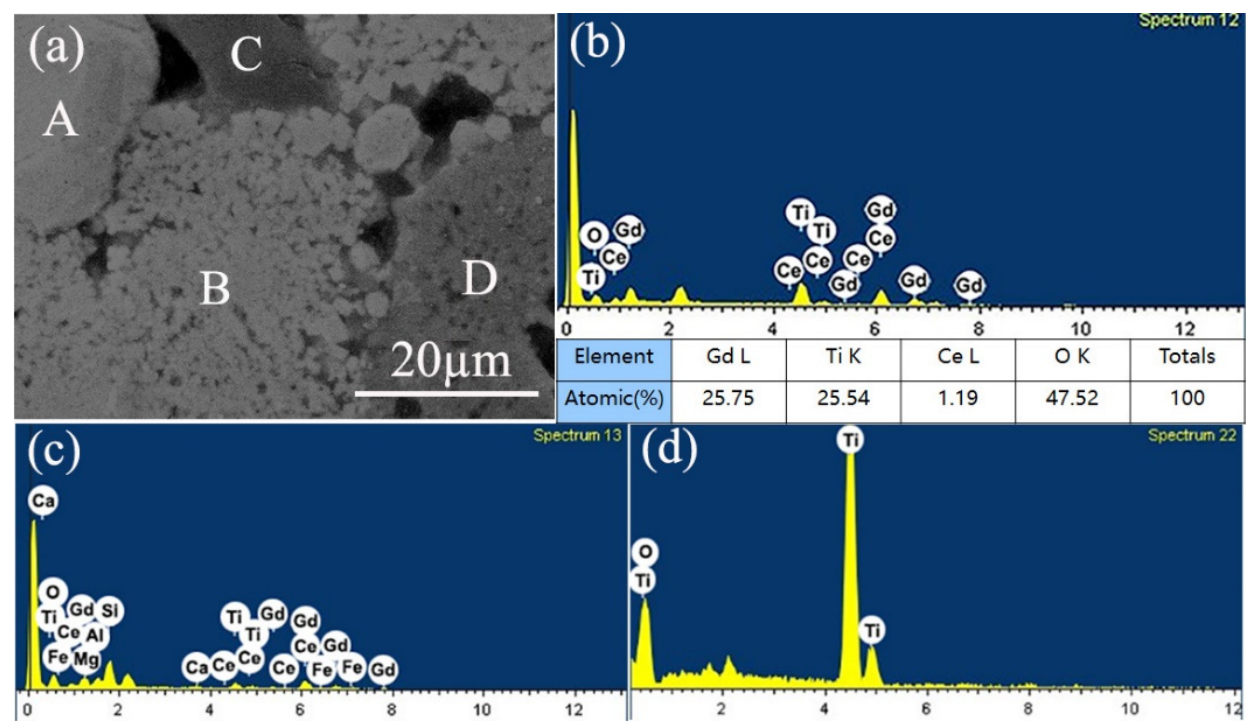

Figure 6. Energy dispersive X-ray spectroscopy (EDX) elemental spotting analysis: (a) Representative SEM image of the Cu-20 sample, (b) EDX spectrum and elemental composition of the labeled " $\mathrm{B}$ " area in (a), (c) EDX spectrum of region C in (a), (d) EDX spectrum of region D in (a).

\subsection{Chemical Durability Measurement by PCT Leaching Test}

The leaching performance of nuclear waste forms is a significant indicator for estimating the chemical stability [37]. The 1-42 days normalized elemental leaching rates of $\mathrm{Si}, \mathrm{Na}$, and $\mathrm{Ce}$ of the $\mathrm{Cu}-20$ sample are depicted in Figure 7. With the extension of soaking time, the normalized leaching rates of $\mathrm{Na}$ and $\mathrm{Si}$ show a downward trend from 1 to 14 days. Then, $N R_{\mathrm{Na}}$ and $N R_{\mathrm{Si}}$ exhibit slight ascension within 14-28 days, and finally both of them reach the lowest values in 42 days. The day 1 and day $42 \mathrm{~N} R_{\mathrm{Si}}$ values are $2.04 \times 10^{-2}$ and $1.86 \times 10^{-3} \mathrm{~g} \cdot \mathrm{m}^{-2} \cdot \mathrm{d}^{-1}$, which represent excellent stability. The lowest value of $N R_{\mathrm{Na}}$ is $1.63 \times 10^{-2} \mathrm{~g} \cdot \mathrm{m}^{-2} \cdot \mathrm{d}^{-1}$ after 42 days of leaching. This rule is not applicable for $\mathrm{Ce}$, whose leaching rate has no definite regulation. The $N R_{C e}$ varies from $7.20 \times 10^{-5} \mathrm{~g} \cdot \mathrm{m}^{-2} \cdot \mathrm{d}^{-1}$ of 42 days to $2.20 \times 10^{-6} \mathrm{~g} \cdot \mathrm{m}^{-2} \cdot \mathrm{d}^{-1}$ of 7 days, which is about five orders of magnitude lower than the $N R_{\mathrm{Na}}$ values. The $N R_{\mathrm{ce}}$ values vary irregularly but remain at a low level $\left(10^{-5}-10^{-6} \mathrm{~g} \cdot \mathrm{m}^{-2} \cdot \mathrm{d}^{-1}\right)$. Compared with our previous research results [38], the leaching rate of Si is slightly lower in this study. The $N R_{\mathrm{Na}}$ of the $\mathrm{Cu}-20$ sample is similar to that of borosilicate glass-ceramics [39]. Nevertheless, the leaching performance of simulated nuclide in $\mathrm{Cu}-20$ sample is significantly lower than that of typical vitreous products [40].

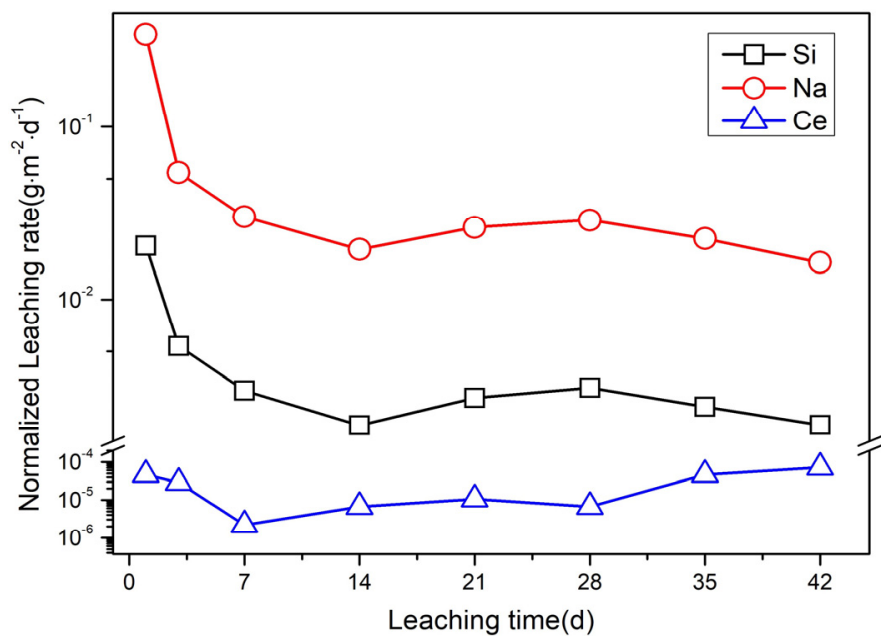

Figure 7. Normalized leaching rates of $\mathrm{Si}, \mathrm{Na}$, and $\mathrm{Ce}$ from day $1-42$. 


\section{Conclusions}

In summary, a series of $\mathrm{Gd}_{2} \mathrm{Ti}_{2} \mathrm{O}_{7}$-based waste forms containing 5-25 wt. $\%$ simulated radioactive contaminated soil have been successfully synthesized by SHS in $5 \mathrm{~min}$. The obtained products are multiphase composite materials composed of $\mathrm{SiO}_{2}, \mathrm{Gd}_{2} \mathrm{Ti}_{2} \mathrm{O}_{7}$, and $\mathrm{Cu}$. Furthermore, the simulated nuclide Ce exists in pyrochlore and soil phases simultaneously, which indicates that Ce migrates partly from soil to pyrochlore phase during the SHS reaction. The solidified body of $\mathrm{Cu}-20$ sample exhibits high stability. The 42 days $N R_{\mathrm{Si}}$ and $N R_{\mathrm{Na}}$ are as low as $1.86 \times 10^{-3}$ and $1.63 \times 10^{-2} \mathrm{~g} \cdot \mathrm{m}^{-2} \cdot \mathrm{d}^{-1}$, respectively. And the $1-42$ days $N R_{C e}$ values also remain at a low level $\left(10^{-5}-10^{-6} \mathrm{~g} \cdot \mathrm{m}^{-2} \cdot \mathrm{d}^{-1}\right)$. Based on the analysis of phase composition, microstructure, and chemical durability, the application potential of SHS technology in the rapid disposal of radioactive soil wastes is revealed.

Author Contributions: Conceptualization, K.Z., B.L. and H.Z.; Methodology, K.Z. and J.X.; Formal Analysis, J.X., K.X., Z.H. and W.Z.; Investigation, J.X., W.L., D.X. and Z.H.; Writing-Original Draft Preparation, J.X.; Writing-Review \& Editing, K.Z. and B.L.

Funding: This research was funded by the National Natural Science Foundation of China (No. 51672228), the Project of State Key Laboratory of Environment-friendly Energy Materials (Southwest University of Science and Technology, No. 16kffk05 and 17FKSY0104) and Science Development Foundation of China Academy of Engineering Physics.

Conflicts of Interest: The authors declare no conflict of interest.

\section{References}

1. International Atomic Energy Agency. Design and Operation of High Level Waste, Vitrification and Storage Facility (Technical Report Series No. 176); IAEA: Vienna, Austria, 1977.

2. Ojovan, M.I.; Lee, W.E. An Introduction to Nuclear Waste Immobilization; Elsevier Ltd.: Oxford, UK, 2005; pp. 213-267.

3. Caurant, D.; Loiseau, P.; Majérus, O.; Aubin-Chevaldonnet, V.; Bardez, I.; Quintas, A. Glasses, Glass-Ceramics and Ceramics for Immobilization of Highly Radioactive Nuclear Wastes; Nova Science Publishers: New York, NY, USA, 2009.

4. Zhu, Y.G.; Shaw, G. Soil contamination with radionuclides and potential remediation. Chemosphere 2000, 41, 121-128. [PubMed]

5. Mao, X.H.; Qin, Z.G.; Yuan, X.N.; Wang, C.M.; Cai, X.N.; Zhao, W.X.; Zhao, K.; Yang, P.; Fan, X.L. Immobilization of simulated radioactive soil waste containing cerium by self-propagating high-temperature synthesis. J. Nucl. Mater. 2013, 443, 428-431. [CrossRef]

6. Gavrilescu, M.; Pavel, L.V.; Cretescu, I. Characterization and remediation of soils contaminated with uranium. J. Hazard. Mater. 2009, 163, 475-510. [CrossRef] [PubMed]

7. Yasunari, T.J.; Stohl, A.; Hayano, R.S.; Burkhart, J.F.; Eckhardt, S.; Yasunari, T. Cesium-137 deposition and contamination of Japanese soils due to the Fukushima nuclear accident. Proc. Natl. Acad. Sci. USA 2011, 108, 19530-19534. [CrossRef] [PubMed]

8. Xie, Y.; Wu, T.; Shi, Z.K.; Zhang, D. A very low level radioactive waste landfill soil characteristics and properties of strontium block. Chem. Res. Appl. 2013, 25, 558-562.

9. Lloyd, J.R.; Renshaw, J.C. Bioremediation of radioactive waste: Radionuclide-microbe interactions in laboratory and field-scale studies. Curr. Opin. Biotech. 2005, 16, 254-260. [CrossRef]

10. Zhang, S.; Ding, Y.; Lu, X.R.; Mao, X.L.; Song, M.X. Rapid and efficient disposal of radioactive contaminated soil using microwave sintering method. Mater. Lett. 2016, 175, 165-168.

11. Zhang, S.; Shu, X.Y.; Chen, S.Z.; Yang, H.M.; Hou, C.X.; Mao, X.L.; Chi, F.T.; Song, M.X.; Lu, X.R. Rapid immobilization of simulated radioactive soil waste by microwave sintering. J. Hazard. Mater. 2017, 337, 20-26. [PubMed]

12. Gin, S.; Abdelouas, A.; Criscenti, L.J.; Ebert, W.L. An international initiative on long-term behavior of high-level nuclear waste glass. Mater. Today 2013, 16, 243-248. [CrossRef]

13. Mccarthy, G.J.; Ebert, W.L.; Roy, R.; Scheetz, B.E. Interactions between nuclear waste and surrounding rock. Nature 1978, 273, 216-217. [CrossRef] 
14. Loiseau, P.; Caurant, D.; Majerus, O.; Baffier, N.; Fillet, C. Crystallization study of $\left(\mathrm{TiO}_{2}, \mathrm{ZrO}_{2}\right)$-rich $\mathrm{SiO}_{2}-\mathrm{Al}_{2} \mathrm{O}_{3}-\mathrm{CaO}$ glasses. Part II. Surface and internal crystallization processes investigated by differential thermal analysis (DTA). J. Mater. Sci. 2003, 38, 843-852.

15. Caurant, D.; Majérus, O.; Loiseau, P.; Bardez, I.; Baffier, N.; Dussossoy, J.L. Crystallization of neodymium-rich phases in silicate glasses developed for nuclear waste immobilization. J. Nucl. Mater. 2006, 354, 143-162.

16. Ringwood, A.E.; Kesson, S.E.; Ware, N.G.; Hibberson, W.; Major, A. Immobilization of high level nuclear reactor wastes in SYNROC. Nature 1979, 278, 219-223. [CrossRef]

17. Franck, P.; John, M.H.; Urs, S. The current state and future of accessory mineral research. Chem. Geol. 2002, 191, 3-24.

18. Vance, E.R. Development of ceramic waste forms for high-level nuclear waste over the last 30 years. Mater. Res. Soc. Symp. Proc. 2006, 985, 135-140. [CrossRef]

19. Weber, W.J.; Navrotsky, A.; Stefanovsky, S.; Vance, E.R.; Vernaz, E. Materials science of high-level nuclear waste immobilization. MRS Bull. 2009, 34, 46-53. [CrossRef]

20. Zhang, K.B.; Yin, D.; Han, P.W.; Zhang, H.B. Two-step synthesis of zirconolite-rich ceramic waste matrice and its physicochemical properties. Int. J. Appl. Ceram. Technol. 2018, 15, 171-178. [CrossRef]

21. Muthuraman, M.; Dhas, N.A.; Patil, K.C. Combustion synthesis of oxide materials for nuclear waste immobilization. Bull. Mater. Sci. 1994, 17, 977-987. [CrossRef]

22. Muthuraman, M.; Patil, K.C.; Senbagaraman, S.; Umarji, A.M. Sintering, microstructure and dilatometric studies of combustion synthesized Synroc phases. Mater. Res. Bull. 1996, 31, 1375-1381. [CrossRef]

23. He, Z.S.; Zhang, K.B.; Xue, J.L.; Zhao, W.W.; Zhang, H.B. Self-propagating chemical furnace synthesis of nanograin $\mathrm{Gd}_{2} \mathrm{Zr}_{2} \mathrm{O}_{7}$ ceramic and its aqueous durability. J. Nucl. Mater. 2018, 512, 385-390. [CrossRef]

24. Zhang, K.B.; Wen, G.J.; Zhang, H.B.; Teng, Y.C. Self-propagating high-temperature synthesis of $\mathrm{Y}_{2} \mathrm{Ti}_{2} \mathrm{O}_{7}$ pyrochlore and its aqueous durability. J. Nucl. Mater. 2015, 465, 1-5.

25. Zhang, K.B.; He, Z.S.; Peng, L.; Zhang, H.B.; Lu, X.R. Self-propagating synthesis of $\mathrm{Y}_{2-\mathrm{x}} \mathrm{Nd}_{\mathrm{x}} \mathrm{Ti}_{2} \mathrm{O}_{7}$ pyrochlore and its aqueous durability as nuclear waste form. Scripta. Mater. 2018, 146, 300-303.

26. Zhang, K.B.; He, Z.S.; Xue, J.L.; Zhao, W.W.; Zhang, H.B. Self-propagating synthesis of $\mathrm{Y}_{2-\mathrm{x}} \mathrm{Nd}_{\mathrm{x}} \mathrm{Ti}_{2} \mathrm{O}_{7}$ pyrochlores using $\mathrm{CuO}$ as the oxidant and its characterizations as waste form. J. Nucl. Mater. 2018, 507, 93-100. [CrossRef]

27. Zhang, K.B.; Yin, D.; Peng, L.; Wu, J.J. Self-propagating synthesis and $\mathrm{CeO}_{2}$ immobilization of zirconolite-rich composites using $\mathrm{CuO}$ as the oxidant. Ceram. Int. 2017, 43, 1415-1423. [CrossRef]

28. Peng, L.; Zhang, K.B.; Yin, D.; Wu, J.J.; He, S.H.; He, H.M. Self-propagating synthesis, mechanical property and aqueous durability of $\mathrm{Gd}_{2} \mathrm{Ti}_{2} \mathrm{O}_{7}$ pyrochlore. Ceram. Int. 2016, 42, 18907-18913. [CrossRef]

29. Peng, L.; Zhang, K.B.; He, Z.S.; Yin, D.; Xue, J.L.; Xu, C.; Zhang, H.B. Self-propagating high-temperature synthesis of $\mathrm{ZrO}_{2}$ incorporated $\mathrm{Gd}_{2} \mathrm{Ti}_{2} \mathrm{O}_{7}$ pyrochlore. J. Adv. Ceram. 2018, 7, 41-49. [CrossRef]

30. He, Z.S.; Zhang, K.B.; Peng, L.; Zhao, W.W.; Xue, J.L.; Zhang, H.B. Self-propagating plus quick pressing synthesis and characterizations of $\mathrm{Gd}_{2-\mathrm{x}} \mathrm{Nd}_{\mathrm{x}} \mathrm{Ti}_{1.3} \mathrm{Zr}_{0.7} \mathrm{O}_{7}(0 \leq \mathrm{x} \leq 1.4)$ pyrochlores. J. Nucl. Mater. 2018, 504, 61-67. [CrossRef]

31. Kim, H.S.; Joung, C.Y.; Lee, B.H.; Oh, J.Y.; Koo, Y.H.; Heimgartner, P. Applicability of $\mathrm{CeO}_{2}$ as a surrogate for $\mathrm{PuO}_{2}$ in a MOX fuel development. J. Nucl. Mater. 2008, 378, 98-104. [CrossRef]

32. ASTM Committee. Standard Test Methods for Determining Chemical Durability of Nuclear, Hazardous, and Mixed Waste Glasses and Multiphase Glass Ceramics: The Product Consistency Test (PCT); ASTM International: West Conshohocken, PA, USA, 2002.

33. Mączka, M.; Hanuza, J.; Hermanowicz, K.; Fuentes, A.F.; Matsuhira, K.; Hiroi, Z. Temperature-dependent Raman scattering studies of the geometrically frustrated pyrochlores $\mathrm{Dy}_{2} \mathrm{Ti}_{2} \mathrm{O}_{7}, \mathrm{Gd}_{2} \mathrm{Ti}_{2} \mathrm{O}_{7}$ and $\mathrm{Er}_{2} \mathrm{Ti}_{2} \mathrm{O}_{7}$. J. Raman Spectrosc. 2008, 39, 537-544. [CrossRef]

34. Mączka, M.; Sanjuán, M.L.; Fuentes, A.F.; Macalik, L.; Hanuza, J.; Matsuhira, K.; Hiroi, Z. Temperaturedependent studies of the geometrically frustrated pyrochlores $\mathrm{Ho}_{2} \mathrm{Ti}_{2} \mathrm{O}_{7}$ and $\mathrm{Dy}_{2} \mathrm{Ti}_{2} \mathrm{O}_{7}$. Phys. Rev. B 2009, 79, 214437. [CrossRef]

35. Zhang, F.X.; Manoun, B.; Saxena, S.K. Pressure-induced order-disorder transitions in pyrochlore $\mathrm{RE}_{2} \mathrm{Ti}_{2} \mathrm{O}_{7}$ $(\mathrm{RE}=\mathrm{Y}, \mathrm{Gd})$. Mater. Lett. 2006, 60, 2773-2776. [CrossRef]

36. Sanjuán, M.L.; Guglieri, C.; DíazMoreno, S.; Aquilanti, G.; Fuentes, A.F.; Olivi, L.; Chaboy, J. Raman and $\mathrm{X}$-ray absorption spectroscopy study of the phase evolution induced by mechanical milling and thermal treatments in $\mathrm{R}_{2} \mathrm{Ti}_{2} \mathrm{O}_{7}$ pyrochlores. Phys. Rev. B 2011, 84, 104207. [CrossRef] 
37. Zhang, Y.; Stewart, M.W.A.; Li, H.; Carter, M.L.; Vance, E.R.; Moricca, S. Zirconolit-rich titanate ceramics for immobilisation of actinides-Waste form/HIP can interactions and chemical durability. J. Nucl. Mater. 2009, 395, 69-74. [CrossRef]

38. Xue, J.L.; Zhang, K.B.; He, Z.H.; Zhao, W.W.; Li, W.W.; Xie, D.Y.; Zhang, H.B. Rapid disposal of simulated Ce-bearing radioactive soil waste using self-propagating synthesized zirconolite-rich waste matrice. Ceram. Int. 2018, 44, 14534-14540.

39. Wu, L.; Li, Y.X.; Teng, Y.C.; Meng, G.L. Preparation and characterization of borosilicate glass-ceramics containing zirconolite and titanite crystalline phases. J. Non-Cryst. Solids 2013, 380, 123-127. [CrossRef]

40. Ojovan, M.I.; Lee, W.E. Glassy Wasteforms for Nuclear Waste Immobilization. Metall. Mater. Trans. A 2011, 42, 837-851. [CrossRef]

(C) 2019 by the authors. Licensee MDPI, Basel, Switzerland. This article is an open access article distributed under the terms and conditions of the Creative Commons Attribution (CC BY) license (http:/ / creativecommons.org/licenses/by/4.0/). 